Primljen / Received: 14.11.2011. Ispravljen / Corrected: 13.8.2012.

Prihvaćen / Accepted: 24.8.2012.

Dostupno online / Available online: 15.9.2012.

\title{
Municipal waste management by hygienization technology
}

Professional paper

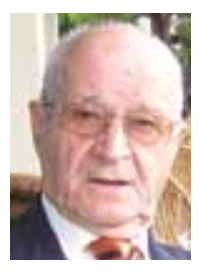

Prof. Jakša Miličić PhD. CE Advisor to the Mayor of Split jaksa.milicic@split.hr

\section{Jakša Miličić}

\section{Municipal waste management by hygienization technology}

The mechanical-biological treatment of waste is often applied in the municipal waste management, which is in accordance with the Strategy of Waste Management in the Republic of Croatia. A relatively great quantity of the so called "dry fraction" is obtained when this technology is used. This dry fraction is baled and sent for thermal treatment. One of the possibilities for thermal treatment of the dry fraction is its use in the cement industry manufacturing processes. This paper provides a detailed analysis of the "hygienization" technology by which the municipal waste is treated in such a way that it can be reused exceptionally well as an alternative fuel in cement plants. The area of the Split-Dalmatia County is covered by the analysis.

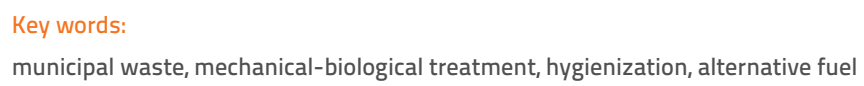

Stručni rad

\section{Jakša Miličić}

\section{Gospodarenje komunalnim otpadom primjenom tehnologije higijenizacije}

U gospodarenju komunalnim otpadom, a u skladu sa Strategijom gospodarenja otpadom u $\mathrm{RH}$, često se primjenjuje mehaničko-biološka obrada (MBO) otpada. Primjenom te tehnologije dobiva se relativno velika količina tzv. suhe frakcije koja se balira i upućuje u toplinsku obradu. Jedna mogućnost toplinske obrade "suhe frakcije" jest u proizvodnim procesima industrije cementa. U radu je napravljena detaljna analiza primjene tehnologije higijenizacije koja posebnim postupkom obrađuje komunalni otpad tako da ga se može iznimno dobro iskoristiti kao tzv. alternativno gorivo u cementarama. Analiza je izrađena za područje Splitsko-dalmatinske županije.

Ključne riječi:

komunalni otpad, mehaničko-biološka obrada, higijenizacija,

Fachbericht

\section{Jakša Miličić}

\section{Kommunale Abfallwirtschaft durch Anwendung der Hygienisierungstechnologie}

In Einklang mit der Abfallwirtschaftsstrategie in der Republik Kroatien wird bei der kommunalen Abfallwirtschaft häufig die mechanisch-biologische Abfallbehandlung (MBA) angewandt. Durch Anwendung dieser Technologie erhält man eine relativ große Menge der so genannten "Trockenfraktion2, die balliert und wärmebehandelt wird. Eine Möglichkeit der Wärmebehandlung der "Trockenfraktion" liegt in den Herstellungsprozessen der Zementindustrie. In der Arbeit ist eine detaillierte Analyse der Anwendung der Technologie der "Hygienisierung" gegeben, die in einem Sonderverfahren den Kommunal-Abfall so behandelt, dass er außerordentlich gut als Alternativbrennstoff in Zementfabriken verwendet werden kann. Die Analyse wurde für die Gespanschaft Split - Dalmatien ausgearbeitet. 


\section{Introduction}

The waste management is regulated by a document called the Waste Management Strategy in the Republic of Croatia [1], and by a special Plan [2] has been determined its realization until 2015. That document which deals with the management of the municipal waste, among others, recommends the mechanical - biological treatment (MBT) technology, and after that technology has been applied, remains a considerable amount of a so-called "dry fraction", which is than baled and sent to the heat treatment facilities. However, this document doesn"t specify either the technology of the heat treatment nor the locations that have been left to the local and regional commitments. In the aforementioned documents, there is nowhere the possibility of the "dry fraction" heat treatment in the cement industry production processes that does exist. Therefore, it"s logical to examine such solution primarily for the needs of the Split - Dalmatia County, and also for the possible needs and opportunities for the remaining three counties in Dalmatia. In this paper, the analysis was applied for the further application of active "hygienization" technology that when applied, in a special way processes the total municipal waste so that the greater part of the remaining product can be used as so called, "alternative fuel".

\section{Municipal waste in Split - Dalmatia County}

The amount of waste that is produced in the Split - Dalmatia County is influenced by several different factors:

1. Total population.

2. Population involved by organized waste collection.

3. The number of tourist"s overnight stays.

According to data based on census of population from 2011, Split - Dalmatia County has a permanent population of 455242 individuals that dwell in total of 156080 households, and waste collection service covers approximately $94 \%$ of the population dwellings. According to [3] in the Split - Dalmatia County per capita is daily produced $1,32 \mathrm{~kg}$ of municipal waste. As a county with developed tourist sector, where is yearly achieved an approximately 6,7 million of overnight stays, tourism in the total municipal waste does matter; it is estimated that tourism alone participates approximately 5\%. According to the Environmental Protection Agency data from November 2011 [3] the amount of produced municipal waste in Croatia is nearly 1,63 millions of tons, i.e. 367 kilograms per inhabitant (approximately $1 \mathrm{~kg}$ / day). However, those figure is still considerably lesser then the European Union countries average value, where such sum is approximately $500 \mathrm{~kg}$ per inhabitant.

In the Split - Dalmatia County during the course of 2005, an approximately $135000 \mathrm{t}$ of municipal waste had been discarded [4], while it was estimated on the basis of the records and surveys of utilities, that industrial waste that was generated in industry, trade and other technological processes in that same year had amounted to almost additional $15000 \mathrm{t}$. It should be noted that such waste differs significantly by its composition from the municipal waste. Accordingly, during the 2005, on the disposals of the Split - Dalmatia County it was brought, therefore, a total of 150000 tons of municipal and industrial waste matters. In accordance to [3], in 2010 total amount of collected communal waste was 223369 tonnes, what is a significant increase when compared to 2005, and which is most probably, the result of a greater efforts for the waste management. The share of the Split - Dalmatia County in the total amount of collected waste in Croatia is 13,88\% [3].

For the needs for the analysis in line with the waste management, the composition of waste is very important. Composition of the communal waste from the Split - Dalmatia County for the year 2005 is shown in Table 1. From the aforementioned data it follows that from the communal waste generated in the Split - Dalmatia County, we can expect a considerable amount of a "dry fraction" per year. If it"s known that the calorific value of the communal waste varies between 12 and $20 \mathrm{MJ} / \mathrm{kg}$ [5], then it can be used as an alternative fuel.

Table 1. The composition of municipal waste of Split - Dalmatia County [4]

\begin{tabular}{|c|c|c|}
\hline Waste type & $\begin{array}{c}\text { Total mass } \\
{[\mathrm{t} / \text { year] }}\end{array}$ & $\begin{array}{c}\text { Percentage share } \\
{[\%]}\end{array}$ \\
\hline Kitchen organic waste & 56.835 & 42,1 \\
\hline Paper and cardboard & 26.865 & 19,9 \\
\hline Skin and bones & 4.185 & 3,1 \\
\hline Wood & 1.755 & 1,3 \\
\hline Textile & 10.665 & 7,9 \\
\hline Glass & 9.045 & 6,7 \\
\hline Metals & 5.535 & 4,1 \\
\hline Inert waste & 2.565 & 1,9 \\
\hline Plastic & 16.200 & 12,0 \\
\hline Rubber & 945 & 0,7 \\
\hline Special waste & 405 & 0,3 \\
\hline Total: & 135.000 & 100 \\
\hline & & \\
\hline
\end{tabular}

\section{Active hygienization technology of municipal waste}

Hygienization is a relatively new technology for managing the municipal waste matters that has been in use since 2010. For the first time it was successfully applied in Spain and it was given the protected name Ambiensys [6]. The machinery for the waste management was installed in one existing building facility with the plant capacity of 25.000 $t$ of waste per year, i.e. 3,8 t/hour. The area on which the manufacturing process has been continually taking place, encompasses $1400 \mathrm{~m}^{2}$ and the main manufacturing process was divided into three units, as it was schematically shown on Picture 1. 
First department - municipal waste acceptance. Municipal waste is brought in by vehicles and filled into acceptance basins (pits); an area which is subjected to a vacuum condition. At an opposite end of the acceptance pit is installed the powerful cutter machine for cutting waste and chopping of the plastic bags that contains municipal waste. It"s about common municipal waste with the wet waste and dry fractions, metals and inert parts.

Second department - municipal waste processing. Thermal waste processing is done with the Geiserbox machine (Picture 2), where with the help of steam (with temperature of $160^{\circ} \mathrm{C}$ and pressure of 6,08 bar) the municipal waste is treated. The waste material travels with the low speed throughout the machine, and the whole process takes about 30 to 35 minutes to complete.

Third department - separation of the municipal waste. After the processing, such treated municipal waste travels into the third (separated) part of the facility where is mechanically sorted and directed, depending on the type and quality of the material obtained.

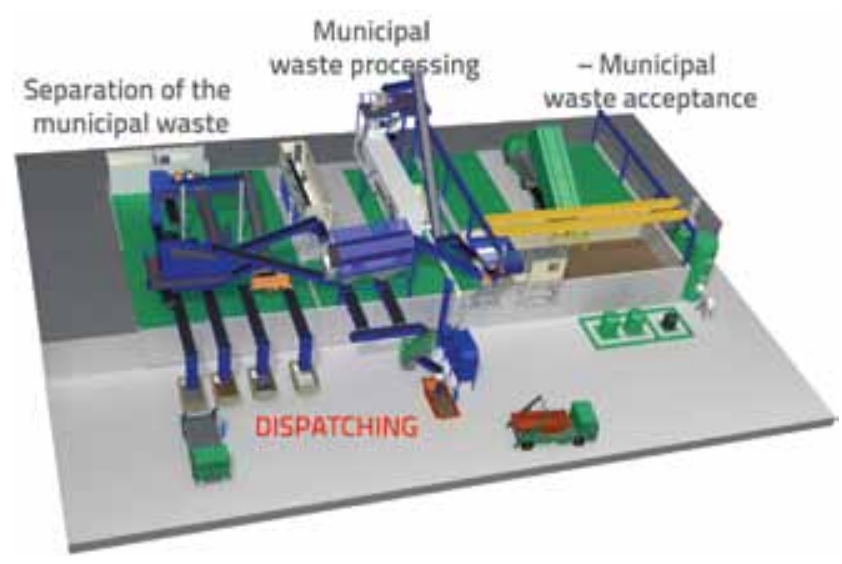

Picture 1. As shown schematically, the processing facilities for the implementation of the "hygienization" process of municipal waste [6]

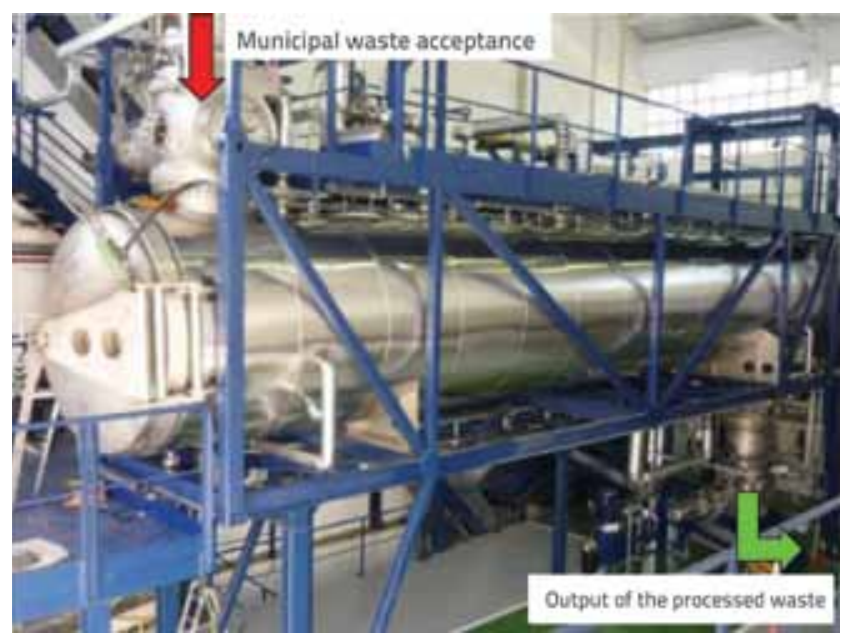

Picture 2. Facilities for the thermal waste processing, Geiserbox [6]
The height of the working area was estimated to be at least $15 \mathrm{~m}$. For the achievement of the aforementioned capacity of $25.000 \mathrm{t} /$ year (or 3,8 $\mathrm{t} / \mathrm{h}$ ), and also for the accommodation room for all three department of manufacturing process, it is necessary to obtain the clear ground area of $1500 \mathrm{~m}^{2}$ with the minimum of $1000 \mathrm{~m}^{2}$ of an additional ground area as an manipulative space. Municipal waste is directly transported into the reception hall where the reception basin is located. Above the basin is mounted the overhead travelling crane with a loader (clamshell grab). Clamshell grab is equipped with multiple jaws (positioned around the bucket) and it could be hydraulically powered. It is installed onto hydraulic crane and it"s used as a mechanical arm for the collecting and transport of loose material and pieces in this particular case, of waste matters (Picture 3).

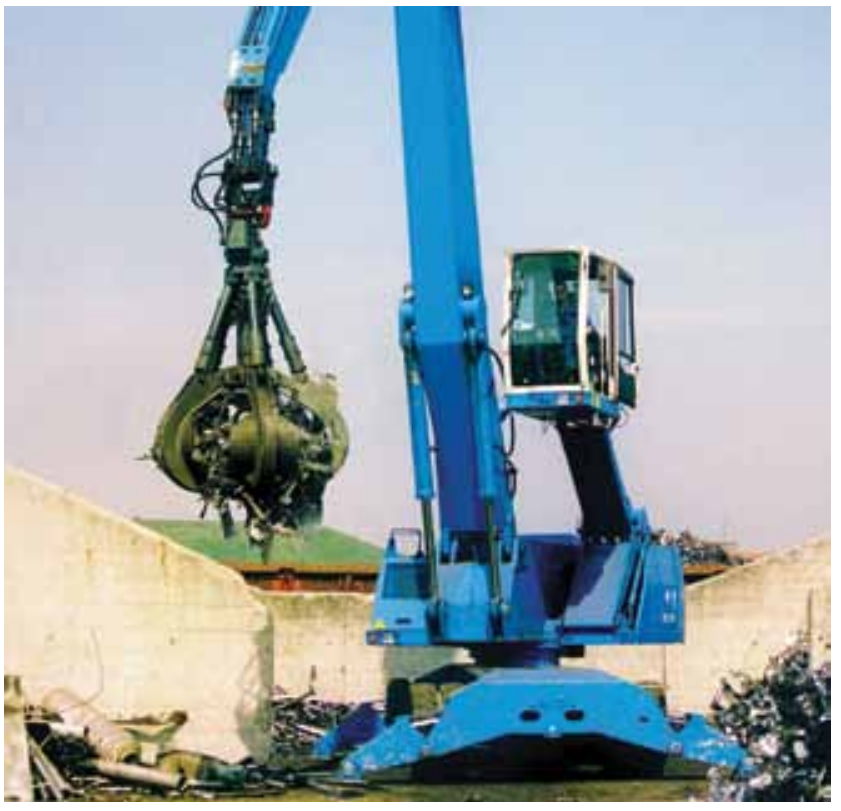

Picture 3. Working description of a clamshell grab during reload of the waste matters [7]

At the end of the basin, on the border with the following production department the powerful cutter machine is installed in which the waste is also fed with the clamshell grab. Such cut waste is transported via band conveyor and so it rises to the point where it enters in the system of Geiserbox, i.e. in the active "hygienization" process (Pictures 1 \& 2). To ensure the continuous work of the facility, during the first part of the process the cut out municipal waste is aggregated in such volume that amounts of a given batch size of the Geiserbox system; the waste is filled into a special cylinder of a machine. Of course, from the cylinder drops out the batch that has already been processed with the same speed. Inside the machine cylinder is incorporated a special worm screw that pushes the waste from the beginning to the end of a process. Hot water vapour is introduced into the cylinder and due to a steam and pressure conditions, the entrance and 
exit of a treated waste materials must be specially regulated. Once the treatment is finished, the waste is discarded in the third department of the processing facility. In accordance to [8] once the active "hygienization" process is finished, such treated municipal waste has no odour; it has become inert and sterilized. During the course of the processing work of the facility, except discarding the hot steam, there are no releases of waste gases or water. The mass of the processed waste is roughly the same as on entrance of the process, but the waste volume is reduced for $80 \%$, i.e. on total $20 \%$ from the total entrance volume, because the waste has been cut and compressed during the process. The processing facility that has been installed in Barcelona process common municipal waste, and it"s composition after the process of "hygienization" has been applied is shown in Table 2.

Table 2. The composition of municipal waste after has been processed in the Geiserbox processing facility

\begin{tabular}{|l|c|}
\hline Structure & Share in mass [\%] \\
\hline Inert waste share (depends on the input quantity) & 5,08 \\
\hline PET packaging & 0,66 \\
\hline Iron & 3,66 \\
\hline Non-ferrous metals & 0,55 \\
\hline "Dry fraction" & 35,18 \\
\hline "Organic fibre" & 54,87 \\
\hline & Total: \\
\hline
\end{tabular}

Inert waste share is directed into particular mound, PET containers are packed and sold at a price of approximately EUR $25 / t$, and iron is also packaged and sold at a price of nearly EUR 45 / t, and non - ferrous metals at a price of 140 EUR / $t$. The remaining mass that is left behind consists of:

- "Dry fraction", which contains plastic (hard), wood, rubber, textile, bones, skin, diapers, etc. and has a calorific value higher than 16,7 MJ / kg, and

- "Organic fibre", that forms the most of the output material. It"s about the wet material that can be dried, and then it will be having a calorific value of 15,5 MJ / kg. Because such material was in a wet condition it may be exposed to the fermentation process for the purpose of compost making.

At the end of the process, "dry fraction" is chopped thus to enable easy thermal processing. PET packaging is separated with optical separator; iron is separated by the use of electromagnet, and non-ferrous metals by means of eddy current effect. In the basic production unit with a capacity of $25.000 \mathrm{t} /$ year, the key feature is a long cylinder of $17 \mathrm{~m}$ in length and $2 \mathrm{~m}$ in diameter: the important elements of this system are parts for input and output of processed waste. The cylinder is located in a special steel construction and size and its fastening are partly conditioned to the circumstances during transport. When dealing with processing machinery, the very important item are their working expenses. At the first installed processing facility in Barcelona with the capacity of 25.000 tonnes of waste per year, operative working costs are 23,75 Euros/tonne. Presentation of all the costs and their share in the production are listed in Table 3 (expressed percentages are in relation to the total manufacturing cost).

Table 3. Shares of the production costs intended for the processing facility for the waste processing using the "hygienization" method.

\begin{tabular}{|l|c|}
\hline Type of cost & Percentage share [\%] \\
\hline Electrical energy & 15,54 \\
\hline Water & 0,29 \\
\hline Gas & 0,62 \\
\hline Water vapour & 5,22 \\
\hline Installations maintenance & 20,97 \\
\hline Work of the employees in the processing plant & 40,09 \\
\hline Maintenance workers & 17,22 \\
\hline
\end{tabular}

According to [6] for the processing facility of $50.000 \mathrm{t} /$ year capacity, lesser operative labour costs were achieved, i.e. 20,90 Euros/hour. Total investment cost for the plant facility of 50.000 tonnes capacity per year, and what also includes utility equipped building ground amounted to about 14,5 millions of Euros. The price that was paid for the waste that was taken (landfill) was 55 euros per one tonne.

Described process of "hygienization" is not perceived in a whole as a Mechanical - Biological Treatment (MBT) of the municipal waste, because from that process the biological treatment has been excluded. This treatment needs to be classified among physical processes of sterilisation using the hot water vapour under pressure in the device called autoclave (autoclaving), i.e. in the part of the processing facility in which the process of sterilisation occurs, when the water vapour is used under the high pressure. Because of the aforementioned, the process of "hygienization" would preferably belong to the group of Mechanical Heat Treatment (MHT) processes. Price of acceptance and treatment of municipal waste with such process should be competitive to the price that is achieved by applying a standard MBT process. If the combustible waste components (dried organic fibres and solid combustible elements) were burned in the cement industry as an alternative fuel, then it could be an environmentally and economically satisfactory solution.

\section{Alternative fuel for the cement plants}

After the process of "hygienization" has taken place, the largest part of municipal waste that is processed is mainly converted into a mass called "organic fibres". During that process the 
volume of everything that is organic is contracted, including paper and cardboard and such mass contains approximately $55 \%$ of moisture. Therefore, given material can be used to produce compost or such mass can be dried in the same plant facility to the $13-15 \%$ level of moisture, with further possibility to use it as an alternative fuel.

Dry material of this composition has, as already mentioned, calorific value of $15,5 \mathrm{MJ} / \mathrm{kg}$. Depending on the acceptability of the chemical composition of that dried mass, it can be used as a good alternative fuel in the cement industry to save and reduce the consumption of fossil fuels. That is especially true when you add the fuel obtained from the fluff RDF, which occurs in the same plant from the chopped solid combustible fuel of high calorific value. However, a material called "organic fibres" can be used in the depolymerization process for obtaining ethanol, which can be even more of interest because of the rise in oil prices.

The technology of "hygienization" is interesting for several reasons:

- From the perspective of the capital investments offers a solution, with an acceptable level of the amount of the investment

- The total input volume of waste is reduced by five times (at about $20 \%$ of the initial volume) which is extremely important

- Total processed waste is "hygienized" (sterilized) and the usable materials (metals, PET, etc.) are separated. Inert components are also separated and the rest of the waste is prepared for the heat treatment:

- "Dry fraction" (wood, rubber, leather, bones, textiles, plastics, etc.)

- "Organic fibres" that needs the drying process.

As we live in times in which the oil is a key source of energy and raw materials, and oil more likely will never be $\$ 15$ per one barrel again, and the much more probable cost per barrel of oil is \$ 100; all of this factors significantly changes all economic events in the world. However, today the energy problems are joined by the environmental problems that are intertwined with each other and clashes, and finally the energy and ecology meet with the economy. So we come to the so called "3 E state"' in which the ecology and energy will find balance and reconciliation only in the field of the economy.

In this case we have the example of exploitation of the so called "dry fraction" from the municipal waste as an alternative energy source intended for the firing of clinker in the cement industry. In fact, dried fraction of municipal waste appears as an alternative energy source with the technological, environmental and economic impacts during the clinker firing process.

According to the aforementioned data from 2010, in the Split - Dalmatia County is produced 220.000 t of municipal waste per year. If that waste was processed using the technology of active "hygienization", than we would get a "dry fraction" with approximately $30 \%$ of mass portion and the often mentioned "organic fibre" fraction with $55 \%$ of mass portion. If "organic fibre" should dry to the level of $13 \%$ to $15 \%$ of moisture content; during that process the mass of the matter will lose around $27 \%$ on the weight. The total processed waste components will have total of $73 \%$ from the input weight of municipal waste. This means we can count on approximately $160.000(220.000 \times 0,73)$ tons of combustible materials per year. Such mass is composed of chopped solid organic waste and dried "organic fibres". Solid waste have to be chopped to a maximum size of 2,5 cm, while the "organic fibres" were already fragmented in the process of "hygienization". Chopping and drying is performed at the same facility where the process of "hygienization" took place and as a prepared alternative fuel is transported to the cement plant.

The costs of storage and transport to the cement plant are up to 20 euros per tonne. We said that this alternative energy source has a calorific value greater than $15 \mathrm{MJ} / \mathrm{kg}$. Energy source that is now using in the cement industry has a calorific value of $36,7 \mathrm{MJ} / \mathrm{kg}$. As a result, a kilo of such energy source that is in use in cement industry is worth as 2,45 kilos of the alternative fuel. This means that 160000 tons of the alternative fuel can replace almost 65000 tonns of the primary energy source, or approximately $40 \%$ in the cement industry of the Split - Dalmatia County.

If the same technology will be used by the other three Dalmatian counties then it could be secured and delivered approximately $90.000 \mathrm{t} /$ year of such combustible substances, which provides an option to replace an almost 39000 tons of the primary fuel. In total, it could be replaced approximately 104000 tons or 68,0 $\%$ from the total primary fuel. For such approach it"s necessary for others Dalmatians counties, too to organize centres in which they will base the same technology and organise "organic fibres" drying and also chopping of the solid waste fraction.

Today, cement plants use alternative fuels to replace fossil fuels, and thus contributed to reducing the consumption of non renewable energy resources. In the world, fuel that is produced by sorting and processing of municipal waste is known as RDF (Refuse Derived Fuel), and can be dispersed in the aforementioned fluff RDF form, baled or to be in the form of briquettes. Fluff RDF as an alternative fuel in cement plants is a substitute for the primary energy source and represents an economic benefit. And it is certainly an economic motive. Fluff RDF as a chopped dry fuel mass is blown into the air stream in the so called "sinter zone" in the cement kiln. In this zone, the temperature of flume gases is about $2000^{\circ} \mathrm{C}$, and the clinker grains reach a temperature of $1500{ }^{\circ} \mathrm{C}$, and then the clinker firing process ends. Under such conditions, clinker surface softened on which than falls and sticks ashes from the burnt fluff RDF. On this way, fluff RDF combustion could be "a process without residues". 
On the basis of analyzes, previously has been demonstrated that the use of fluff RDF as an alternative energy source [9]

- Do not affect the quality of the product (cement)

- Have no adverse impacts on the technological process

- Does not adversely affect the capacity of the kiln

- There are no adverse effects of chlorine because it is kept under control by special procedures.

These effects are reflected in the fact that the composition of flue gases released into the atmosphere for its chemical composition is more favourable than the composition of gases when such fuel is not used. At least, with the respect to the content of carbon dioxide when a fluff RDF as an alternative energy source is used, the content of carbon dioxide in flue gases is proportionally reduced. Also the time of combustion of fluff RDF in the "sinter zone" lasts from 5 to 7 seconds which is quite sufficient for complete combustion, and thus for the quality of emitted gases.

There is an additional economic interest in the fact that these kilns for the heat treatment of "dry fraction" obtained from municipal waste already exists and there is no need to build them anew. Therefore, the Split - Dalmatia County and also the other Dalmatian counties can solve the problem of waste quickly, efficiently and environmentally exceptionally well with minimalAll of course depends on whether the cement industry will accept such "alternative energy source". Although there are strong reasons for the aforementioned, however, it depends on their decision, but the strict regulations of the European Union will be an incentive. While it will not be able to avoid the discussion under what conditions the cement industry will be prepared to use this "alternative energy source". It can be more than one solution:

- That local government is to pay a certain price to the cement industry for the received amounts of "alternative energy source"

- Cement industry is to pay the local community a certain price for the received amounts of "alternative energy source", or

- The cement industry will take over an "alternative energy source" in the processing facilities by its own vehicles without any compensation.

The great advantage of this technology is that these aforementioned facilities for the "hygienization" process could produce alternative energy source by our industry, as our own product.

\section{The selection of location and costs of the technology introduction}

The application of the "hygienization" technology for the treatment of municipal waste in the Split - Dalmatia County creates a need for the discussion of the site selection. Namely, the capacity of a one processing facility (plant) provides an opportunity for treatment of municipal waste of $25.000 \mathrm{t} /$ year or 3,8 tons / h. Thus, plant for a treatment of municipal waste in the Split - Dalmatia County, depending on the capacity of the plant, may be organized as a centralized facility in Lećevica which has been envisioned by the county"s regional plan with several "hygienization" process parallel lines, or as a decentralized system, with regard to the geographical features that would comprise of e.g.:

- Plant in Split (including the islands), equipped with three lines

- Plant Solin - Kaštela - Trogir, equipped with one line

- Plant in Sinj and Omiš, equipped with one line, or

- Plant Imotski - Makarska - Vrgorac, equipped with one line.

Decentralization would certainly reduce shipping costs, but it will also increase the investment and exploitation costs. The most important fact is that while the location in Lećevica is provided through the County Regional plans as a regional centre for the waste management, but for the other locations it would be necessary up to two years to have all the approvals for the implementation of MBO (MBT) technology there. Therefore, at the moment in order to fully address the problem of municipal waste in the Split - Dalmatia County is only practicable at the Lećevica location. Also, because of a capacity of the production units "hygienization" technology offers the possibility of a gradual increase in capacity, depending on the need and opportunities. In the analysis that were made within this paper and related for solving the problem of municipal waste in the Split - Dalmatia County, only the processing plant that will be located in Lecevica is considered. That plant would have nine (9) units of a standard capacity (220.000 tons/year / / 25.000 tons/year; that"s equal of 8,8 processing units).

If we take into consideration total amount of municipal waste in the Split - Dalmatia County of approximately 220.000 tons per one year [3] and also to reckon on the experience from Barcelona that were listed in Table 2 then, at the end of the "hygienization" process the composition of processed waste would be as it was shown in Table 4.

Table 4. Composition of processed waste from the Split - Dalmatia County after the completion of the "hygienization" process

\begin{tabular}{|c|c|}
\hline Structure & Percentage share $[t]$ \\
\hline Inert share & 11.176 \\
\hline PET packaging & 1.452 \\
\hline Iron & 8.052 \\
\hline Non - ferrous metals & 1.210 \\
\hline "Dry fraction" (rubber, wood, leather, textile etc.) & 77.396 \\
\hline Special fraction - "organic fibres" & 120.714 \\
\hline Total: & 220.000 \\
\hline
\end{tabular}


All these shares that are presented in Table 4 are of only approximate size. For the total nine (9) units is required a hall of layout area of at least $9000 \mathrm{~m}^{2}$. All units should be under one roof, but physically divided into three separate units, as this type of technology demands:

- Unit for municipal waste acceptance that is subjected to a vacuum condition

- Unit for the active "hygienization" process with Geiserbox machines (9 pieces of machinery)

- Unit for the physical separation (categorization) of processed matter.

From the total area of production halls, the first phase of the process (waste reception) would cover approximately $30 \%$; the second phase (hygienization process) would cover approximately $25 \%$, while the third phase (physical separation) would cover approximately $45 \%$ of the production area. Besides aforementioned there is a need to calculate yet another, nearly $5000 \mathrm{~m}^{2}$ of ground area needed for the manipulation processes. Therefore, to create one modern centre equipped for the waste management, by means of the "hygienization" process, we should need in total $14.000 \mathrm{~m}^{2}$ of utility equipped ground area.

According to our estimations, the terrain area should cost approximately 200 thousand Euros. Expenses for the insurances for the necessary infrastructure, so the plant could work (that includes running water, natural gas, road infrastructure) would amount approximately to 2 millions of Euros. Investments in the ground area and necessary infrastructure shall amount about 2,2 millions of Euros. If we anticipate that the building price of industrial hall for such manufacturing utility would cost about 400 Euros per square meter, than the price of the whole building edifice would be approximately 3,6 millions of Euros. If we also take into consideration the accompanying buildings, then the price of construction works on such building edifices would be estimated at 4,2 millions of Euros.

According to the experiences gained in Spain in relation to the price of the construction works, the value of the installed manufacturing with the capacity of $220.000 \mathrm{t} / \mathrm{year}$ is estimated at 60 millions of Euros. It should be added the amount for the installation of the dry kilns, each with the working capacity of $2 \mathrm{t} /$ hour, what would amounts in total of 500.000 Euros. It is estimated that will be almost $120.000 \mathrm{t} /$ year of the so called organic fraction, which then will be sent into the system of dry kilns; with each unit of dry kiln has a capacity of $2 \mathrm{t}$ /hour, then, when considering 6000 working hours per one year (i.e. 300 working days per one year), we need to have 10 drying units (kilns), i.e. total investment value of nearly 5 millions of Euros. Aforementioned costs necessary for the construction building and equipping the manufacturing plant for management of the utility waste, by applying the technology of "hygienization" are listed in Table 5. According to experiences derived from the similar plant in Spain, and in accordance with calculations that were derived from the plant of $25000 \mathrm{t} /$ year capacity, we"ve got the operational plant costs (Table 6). As it can be seen from the Table, without the capital cost and without taxes and similar imposts, the manufacturing (production) price would be approximately 21,5 Euro per 1 tonne of imported waste. If we observe the possibility of such investment in the Republic of Croatia, for the acquirement of precise calculations, first it"s necessary to have a reliable data not only about the costs of the plant, but also more precise data about the waste itself.

Table 5. An estimated investment value into the processing facility of 220.000 t/year capacity

\begin{tabular}{|l|c|}
\hline Investment & $\begin{array}{c}\text { Amount } \\
\text { [mil. eura] }\end{array}$ \\
\hline Building ground equipped for the utilities & 2.2 \\
\hline Manufacturing and accompanying facilities & 3.6 \\
\hline Total manufacturing plant with the 220.000 t/year capacity & 60.0 \\
\hline Dry kilns with 10 units, with the construction part included & 5.0 \\
\hline & Total: \\
\hline
\end{tabular}

Table 6. Manufacturing plant operative costs per one tonne of waste

\begin{tabular}{|c|c|}
\hline Type of costs & Cost [eura/t] \\
\hline Energy & 2,94 \\
\hline Material necessary for the process & 1,78 \\
\hline Maintenance work & 1,71 \\
\hline Operative work (labour force) & 8,05 \\
\hline Water & 0,01 \\
\hline Cost of the dry kilns working cycles & 7,0 \\
\hline Total: & 21,49 \\
\hline
\end{tabular}

\section{Conclusion}

The discussed technology would solve the problem of municipal waste in the Split - Dalmatia County on an environmentally extremely satisfactory way. Basically, the sanitary landfill could be excluded and it would be left only for the safety reasons, and that would also need to be assessed and taken into the calculations. Exploitation of the alternative fuel in the cement industry would significantly reduce emissions of carbon dioxide and added the appropriate economic dimension. On the Lećevica location there would be no danger for the wastewaters percolation into the underground layers and waters, and also there would be no combustion and gas emissions in the area. 


\section{REFERENCES}

[1] Strategija gospodarenja otpadom Republike Hrvatske, Narodne novine 130/2005

[2] Plan gospodarenja otpadom u Republici Hrvatskoj za razdoblje 2007. - 2015., Narodne novine 85/ 2007.

[3] Izvješće o komunalnom otpadu za 2010. godinu, Agencija za zaštitu okoliša, studeni 2011.

[4] Plan gospodarenja otpadom u Splitsko-dalmatinskoj županiji, Službeni glasnik Splitsko-dalmatinske županije 1B., 2008.

[5] Prelec, Z.: Porijeklo i osobine otpada, www.riteh.uniri.hr/zav_ katd_sluz/zvd_teh_term.../9.pdf.

[6] www.ambiensys.es

[7] http://www.iwea.eu/hr/oprema_grabezi.htm

[8] Santiago Vila Danès, Municipal waste management, Conference "Embracing a comprehensive European waste policy", European Week for Sustainable Energy, Brussels, 19 ${ }^{\text {th }}$ June 2012.

[9] Popović. K., Miličić. J., Milanović. Z., Moguća uloga hrvatske industrije cementa u sustavu gospodarenja otpadom, IGH, Zagreb, 1999 